\title{
Religious Pluralism in Ghana: Using the Accommodative Nature of African Indigenous Religion (AIR) as a Source for Religious Tolerance and Peaceful Coexistence
}

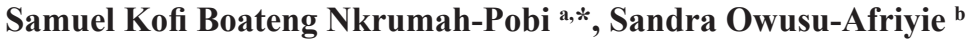 \\ ${ }^{a}$ Yonsei University, Yonsei International Campus, South Korea; ${ }^{b}$ University of Ghana, \\ School of Nursing and Midwifery, Ghana. \\ *<samuelnkrumahpobi@gmail.com>
}

\begin{abstract}
This article deploys the accommodative nature of African Indigenous Religion (AIR) as a reflective tool in Ghana's religious pluralistic context. This paper argues that the accommodative nature of AIR which has made scholars argue for its singularity can serve as a tool which would promote religious tolerance and peaceful coexistence in Ghana. The findings of the research demonstrated that though there is a level of religious tolerance and peaceful coexistence among various religious groups in Ghana, there is still more room for improvement, thus the proposal of this model as a response.
\end{abstract}

Keywords: African indigenous religion, religious tolerance, peaceful coexistence

\section{Introduction}

Unlike Europe and the United States of America which recently felt the wind of religious pluralism,[1] continents such as Asia (East)[2] and Africa were living with the phenomenon where the various religions lived in peace and harmony before its encounter with European traders and missionaries. [3] This encounter introduced another form of religion known as 'Christianity' to the continent, as well as 'Islam' which found its way to the continent through wars in North Africa and trade in sub-Saharan Africa. These have enriched the religious plurality of the continent though it came with both negative and positive implications.[4]

These encounters have contributed in making the continent feel the strong 
impact of religious pluralism, which includes Ghana. In Ghana, there are three main religions that are recognized though other minor religions exist. These recognized religions include Christianity, Islam and African Indigenous Religion. Also, within these religions, one can observe another form of pluralism since these religions also come along with various sects, divisions and denominations.[5] In both the public and private spaces in Ghana, one can identify the presence of different religious practitioners, [6] thus the need for such people to tolerate each other. This is because the absence of such tolerance can serve as a threat to the peace the country is currently enjoying. This calls for a model or idea which shall serve as a direction to these people with different religious orientations. This paper thus attempts to reclaim the ideals of AIR in constructing a model for tolerance in a religious pluralistic country like Ghana.

This study is based on the analysis of various secondary data resources focusing on the reclaiming ideals from AIR for the construction of an environment of religious pluralism. This research shall be situated in Ghana, a country characterized by various forms of religious pluralism. Data from the internet, published and unpublished literature on religious pluralism in Ghana were reviewed. These were in the form of books and journal articles. This study therefore explores ideals from
AIR as basis for the construction of this environment of religious pluralism in Ghana. This study is necessary because if issues of peaceful coexistence and tolerance are not addressed, it would result in conflict which can escalate into a civil war, breaching the peace enjoyed in the country at the moment.

\section{Literature Review}

In an attempt to describe what religious pluralism means, Ed Goran Collste asserts that religious pluralism denotes an environment of the existence of more than one religion.[7] While Elise Roumeas on the other hand noted that religious pluralism in its theological form depicts a certain attitude towards religion plurality which is a religious response to the appreciation of diversity that demands for an equal recognition of various religious differences. [8] Irene N. Osemeka postulates that religious diversity and pluralism are used interchangeably to describe the wide range of religious faiths that exists. She noted that religious diversity points out the differences in religious faiths whereas religious pluralism is "synonymous with freedom of worship and expression" but its main focus is on the idea of, "live and let live".[9] Diana Eck, based on this understanding argues that religious pluralism requires "an energetic engagement with diversities". [10] In light of this engagement, Konadu points out that there is a level of religious tolerance and cooperation 
in Ghana which has both positive and negative effects.[11] Nora Kofognotera Nonterach on the one hand noted that the "misuse" and "misunderstanding" of religion in Ghana has been a source of conflict.[12] In an attempt by the Church to address this conflict, Michael Fuseini Wandusim argues that there has been tensions and some propositions in combing the tasks of dialogue and the proclamation of the gospel in interacting with people of other faith. [13] This assertion by Wandusim was seen differently by Emmanuel Martey, who argues that, interreligious dialogue and praxis helps Christians to learn how to walk together with their neighbours confronting struggles such as poverty, oppression, injustice, sexism, racism etc. and celebrating life together.[14] This motive of interreligious dialogue as argued by Martey is in line with that of Jürgen Moltmann who argued that missions should be seen as the invitation to that indirect dialogue about the present dangers to the world, and ways of surmounting them.[15] Likewise, Paul Knitter argues for a form of dialogue devoid of theological or spiritual aspects of religions, but rather focuses on a practical, ethical, globally responsible dialogue in which Christians, among themselves and together with people of other religious faith, can work, act, talk and pray together in order to save this dying earth from suffering and crises.[16] This is an attempt by scholars and theologians to resolve such conflicts that confronts or shrouds dialogue.

This tension in dialogue on the other hand, could also be as a result of the worldview of how the Church approaches people of other faith. This might be probably because the Church's orientation and approach to dialogue is Western in nature, thus the need to approach this dialogue from an African perspective. Hence, this paper tries to explore how Africans having different religions were able to live in toleration without or with little problems and constructing a model from this relationship as a tool in addressing religious pluralism. It must be noted that from the literature so far reviewed, it seems little or no research has been done on using ideals from AIR to respond to issues of religious pluralism in Ghana. This is the gap that this research seeks to fill.

\section{Religious Demography of Ghana}

According to the Ghana Statistics Services report on the 2010 census in Ghana, it was noted that the population of Ghana was at 24, 658, 823 . The report noted that $71.2 \%$ of the population professed faith in Christianity, while $17.6 \%$ said they adhere to the Islamic faith. The report also suggested that $5.2 \%$ practiced traditional religion, whereas $5.3 \%$ were not affiliated to any religion. [17] The United States Department 
of State report in 2018 estimated the population of Ghana to be a total of 28.1 million. The report in reference to the 2010 population census on religious demography added that out of the $6 \%$ who were not affiliated to any religion, some belonged to smaller religious groups such as the Baha'i Faith, Buddhism, Judaism, Hinduism, Shintoism, Eckankar, and Rastafarianism. The Christian population according to the report came with people being affiliated to different denominations such as Catholics, Protestants, African Indigenous Churches, Pentecostal/ Charismatics and other denominations. Also, among the Islamic community were sub-communities such as the Sunnis, Ahmadis, Shias, and Sufis (Tijaniyah and Qadiriyya orders). The report further noted that there are some groups that combined Christianity or Islam with traditional beliefs as well as a belief system called Zetahil which is unique to Ghana; a combination of both Christianity and Islam.[18]

\section{Christian-Islamic Relations in Ghana}

From the above statistics, it can be noted that the two main religions with large following in Ghana are Christianity and Islam, thus this section would focus on the relations which exists between these two religions. In the Northern part of Ghana, majority of the residence are Muslims with
Christians being in the minority. As a result of this, there are occasional violence outbreaks among these two religions which is not only found in the Northern part of Ghana, but also across the entire country. In this regard, the Presbyterian Church of Ghana (PCG) responded by the institution of the 'Presbyterian Inter-Faith Research and Resource Centre (PIRRC).' This centre holds the view that the cause of religious conflicts is as a result of the lack of knowledge and dialogue between religions. Dr Solomon SuleSaa, who happens to be a converted Muslim and Dean of PCG in the Northern Presbytery states as follows: "Ignorance leads to fear and mistrust, but deeper understanding and respect for others and their faith brings peace". [19] The PIRRC engages in interfaith dialogues by the organization of conferences, seminars, symposiums and workshops with themes focusing on the relationship between Christians and Muslims from both theological and socio-political perspectives, good neighbourliness and peaceful coexistence. One cannot comment on efforts being made by the Church by ensuring dialogue without making mention also of the efforts by the Islamic community. Two major events marked the 100th birthday celebration of the current National Chief Imam of Ghana, Sheikh Osman Nuhu Sharubutu. The first was a lecture held in his honour under the theme, "Advancement 
of Modern Ghanaian Society through Peace, Tolerance and Development"[20] and afterwards his visit to the Christ the King Catholic Church in Accra as part of his thanksgiving service, where he worshipped with the congregation.[21]

One therefore could observe the efforts being made by both religious groups to ensure a level of peace and tolerance. In spite of these efforts which are most often characterized by conferences, public lectures and symposiums, scholars like Mustapha Abdul-Hamid do not adhere to this approach, arguing that Christians and Muslims have lived peacefully in Ghana since the fifteenth century. $\mathrm{He}$ further noted that one of the best ways in which Christians and Muslims in Ghana can continue with this relationship is by "dialogue of life" rather than the organization of conference meetings and half-hearted handshakes.[22] Joyce Rhoda Akuaku on the other hand argued that in High schools in Ghana, there exists a relative peaceful coexistence between the two religions, irrespective of this, are traces of negative perceptions which persists between adherents of these religious groups towards each other. She noted that Christians perceives Muslims as not being patient and being violent in nature, while Muslims on the other hand sees Christians as exclusivist who think highly of their religion.[23] Emmanuel Obeng-Mireku on the other hand observed that social, economic, institutional and media factors are important contributing elements for the kind of relationship that exists between Christians and Muslims in Ghana. [24] Wandusim further noted that an important aspect of the ChristianMuslim relation is the involvement of young people in the process of dialogue since they represent the future of the faith.[25] Cosmas Justice Ebo Sarbah on the other hand shifts the discussions which exists between Christians and Muslims in terms of their relationship from the theological and historical dimensions to that which comprise of religious and socio-political practicalities and issues, which have the tendency for the formulation of images and attitudes of the other religious traditions but also help bring effectual and meaningful Christian-Muslim encounter.[26] Consequently, in order to embark on this journey, one must also access the nature of AIR which existed on the continent before the coming of these two religions to better foster this encounter.

\section{Nature of African Indigenous Religions (AIR)}

One may ask if AIR is homogeneity or multiplicity of religions? Scholars such as Namawu Alhassan Alolo have argued that there has been a longstanding issue in the way AIR should be perceived, that is if its practices and beliefs should be regarded as a singular religion or a series of practices 
and expressions which depicts shared views of reality.[27] Scholars from diverse backgrounds such as theology, anthropology and sociology have argued that AIR is a multiplicity of religions. Notable among such scholars was John Mbiti who argued for the conception of the indigenous religions of Africa as diverse religions. In one of his publications, Mbiti asserted that:

We speak of African traditional religions in the plural because there are about one thousand African people (tribes), and each has its own religious system. These religions are reality which calls for academic scrutiny and which must be reckoned within modern fields of life like economics... [28]

Thus, Mbiti considers AIR a heterogeneous religion because of its different belief systems, rituals, ceremonies and leadership nature. In like manner, J.S. Booth has argued that:

Our reading and observation turn up a profusion of phenomena to which we may attach such labels as supreme gods [sic], nature spirits, ancestor rituals, initiation practices... and demons with considerable variety from place to place. Perhaps we will decide that there is no such thing as 'African Religion', but 'African Religions'.[29]

Even though these scholars acknowledge the heterogeneity of AIR, scholars like Laurenti Magesa argues otherwise. He argues that AIR is homogenous in nature, making reference to the conference of missionaries in Le Zoute, Belgium which acknowledged its homogeneity. [30] The Le Zoute conference recognized the diversities marking Africa in terms of its geography, languages, and sometimes the physical appearance of its people. It noted that there was an essential unity which underlined its divergence.[31] J.V. Taylor as cited by Alyward Shorter asserts that AIR should be considered as a single religion with the same basic worldview, though its varying expressions cannot be ruled out. [32] Bolaji Idowu on the other hand observed that African traditional belief stems from one religious tradition and should be termed as 'African traditional religion'.[33] What these scholars try to establish is that, variety within a particular religion, in respect to AIR, does not suggest that there is diversity in the fundamental beliefs, thus rules out the notion of its multiplicities. In this regard, AIR should be understood as a singular religion, with diversity in its expressions and the implementation of its ideals by the different people of Africa. Magesa puts it this way:

If we study African Religion in a specific place among a specific ethnic group, as many scholars have done and still do - and, indeed, as it is necessary to continue to do - it is for the sake of depth and should not be used to support the argument that African Religion is not a generic whole. Obviously, the actual implementation of African religious ideals differs from place to place. This is illustrated most clearly by those religious expressions of African origin in the Diaspora, in Brazil, Surinam and the Caribbean, for instance. In spite of the fact that these people trace their ancestry to Africa through many generations, 
the African kernel of their religious thought-systems and expressions is unmistakable. Their religion has developed distinctive practices, and even borrowed from the Catholicism predominant in some of those regions. But they [sic] are still a form of African Traditional Religion...[34]

From the arguments by these scholars, there is a form of consensus that AIR should be seen as a singular religion, though in the perspective of the authors of this article, we adhere to the first arguments by Mbiti and Booth that it is a multiplicity of religions. If the argument raised by Idowu arguing that the foundation of AIR contributes it to being a singular religion, then what about the Abrahamic religions like Judaism, Christianity and Islam which are rooted in a single religious tradition? Are they also to be considered as singular in nature? How come AIRs with its diverse nature and different understanding of the Supreme Being and human nature have been able to attain singularity as argued by these scholars? In answering this question, we would argue that the acceptance nature of AIR has been a contributing factor as well as the understanding that one person cannot conceive the Divine, thus giving room to accepting people with diverse religious understanding and views, and arguing that this form of understanding if tapped into can help promote religious tolerance in Ghana.

\section{Accommodative nature of AIR as basis for Religious Toler- ance in Ghana}

We admit that though this form of accommodative model which was evident in AIRs that we proposed for the religious pluralistic context of Ghana might be problematic, it is worth to explore and approach it with a more open mind. This model of accommodation which was expressed within the African religious perspective, enabled one to visit several shrines to seek assistance though the modus operandi of these shrines might differ. That was because each god was seen with special qualities, for example, "Tegare" was seen as a god of war, while "Antoa" was famously known for vengeance in the Ghanaian setting.[35] It must be noted that this was possible because of the conceptual understanding of the nature of God. This nature is expressed in the language and songs of the people. For example, a popular Akan proverb asserts that, "Wisdom is like baobab tree; no one individual can embrace it".[36] This assertion goes on to establish the fact that one single person cannot claim to possess all wisdom or the way of life. This thus can include the understanding of the Supreme Being and His/her ways and how one ought to please Him/ Her. Another famous Akan proverb translates "Wisdom cannot be found in one person's head." This makes one understand the reality of life that 
no single religion has all the answers and wisdom to solve every problem in life and bring peace and fulfilment to the soul. This means that wisdom is interdependent in the religious pluralistic context in which Ghana finds itself. Each religion cannot be sufficient in knowledge and wisdom, it takes this accommodative approach to tolerance and peaceful coexistence for one religion to learn and grow from another in order to thrive and understand their own belief systems. This notion thus compels them to embrace wisdom from all walks of life irrespective of the form or nature it takes.

With this understanding about the Divine, various religions in Ghana must adopt this approach by acknowledging that no single religion is a possessor of the truth but carriers of a truth. This understanding should shift from just its mere conceptual form to assume its practical form. Since it has been established by various scholars that the God that the missionaries brought to the continent is the same God that the people already were worshipping, then it suggests that our approach towards the Divine being can be fused together. By fusion we imply Christians, Muslims and people of other religious jurisdiction alike practicing each other's way of life with harmony. This would mean a Muslim can go to the Church to seek consultation from the Pastor as well as the Christian visiting the Imam for help, and also, both visiting the Chief Priest for assistance and vice versa. This model would go a long way to promote religious tolerance in Ghana. We must admit that in terms of practicality, we might not be the first to suggest this way of life since the population census presented earlier demonstrates traces of such way of living, but we have taken it a step further.

\section{Conclusion}

The paper has presented the religious overview of Ghana, focusing on the Christian-Muslim relations and assessing the nature of AIR which inspiration was drawn from to present an accommodative model based on the nature of AIR to contribute to tolerance among religious groups in Ghana. This paper has highlighted the significance of the AIR as its belief systems and practices serves as a model in bridging the differences between the other religions in Ghana. AIR in its accommodative nature will foster interdependence between the various religions in Ghana, adding to the tolerance and peaceful coexistence people from diverse religious walks enjoy in the country if the model is fully implemented. This accommodative model, the researchers believe if expanded to the other parts of the globe, can help nurture the tolerance and peaceful coexistence needed and heal the scars religion has imprinted on our world.[] 


\section{References}

[1] D. H. Davis, Introduction: Religious Pluralism as the Essential Foundation of America's Quest for Unity and Order. The Oxford Handbook of Church and State in the United States, 2011.

[2] E. Menegon and G Cogan, "Religious change in East Asia," in Religion and Religious Change, ed(s) Jerry H. Bentley, Sanjay Subrahmanyam, and Merry E. WiesnerHanks. Cambridge University Press, 2015, pp. 387-422. DOI: https://doi.org/10.1017/ CBO9781139022460.017.

[3] B. Møller, Religion and Conflict in Africa With A Special Focus on East Africa. Danish Institute for International Studies, Diis Report 6,2006, pp.12.

[4] Møller, Religion and Conflict in Africa, 19-33.

[5] S. Nathan Iddrisu, "I am Because We Are: A Precondition to Peace in a Religious and Political Pluralistic West African Country," Journal of Applied Thought: A Multidisciplinary Approach Vol. 3, No.1, (2014):44

[6] A. Konadu, "Religious Pluralism and its Effects on Ghanaian Society," GRIN (2018):1.

[7] E. Göran Collste, Religious and Ethnic Pluralism in Malaysia. Linköping: University Electronic Press,2006, pp. 10.

[8] É. Rouméas, "What Is Religious Pluralism?” In Religious Pluralism: A Resource Book, ed(s) Bardon, Aurélia; Birnbaum, Maria; Lee, Lois; Stoeckl, Kristina And Roy, Olivier. Florence: European University Institute, ReligioWest, 2015, pp.12.

[9] I. N. Osemeka, "The Management of Religious Diversity in West Africa: The Exceptionalism of The Wolof And Yoruba In the Post-Independence Period," Historia Actual Online, No. 33 (2014): 62.

[10] D. L. Eck, "What is Pluralism?" http;/www.academiacroom.com/topic/religious. (Accessed December 2019).

[11] Konadu, "Religious Pluralism,"1.

[12] N. Kofognotera Nonterah, "The Challenges of Interfaith Relations in Ghana," In Pathways for Interreligious Dialogue in the Twenty-First Century. Pathways for Ecumenical and Interreligious Dialogue (ed)s. Latinovic V., Mannion G., Phan P.C. New York: Palgrave Macmillan, 2016.

[13] M. Fuseini Wandusim, "Interfaith Dialogue and Christian Witness: Exploring the Challenges and Tensions Involved from a Ghanaian Perspective," Journal of Advocacy, Research and Education Vol. 3, No.2, (2015):166.

[14] E. Martey, "The Challenge of Inter-Religious Dialogue and Praxis to the African Theological Community," A Paper Presented to World Conference of Associations of Theological Institutions, 2008.

[15] J. Moltmann, "Dialogue or Mission? Christianity and the Religions in an Endangered" World in Christianity and Other Religions Selected Readings, ed(s), John Hick and Brian Hebblethwaite (Oneworld Publications, 2001).

[16] P. F. Knitter, Introducing Theologies of Religions. Maryknoll, New York: Orbis Books,2002.

[17] Ghana Statistical Service [GSS], 2010 Population \& Housing Census: Summary Report of Final Results. Accra, Ghana: Ghana Statistical Service, 2012.

[18] United States Department of State, Bureau of Democracy, Human Rights, and Labour, "Ghana 2018 International Religious Freedom Report," https:/www.state. gov/wp-content/uploads/2019/05/GHANA-2018-INTERNATIONAL-RELIGIOUS- 
FREEDOM-REPORT.pdf. (Accessed December 2019).

[19] Evangelical Mission in Solidarity, "Ghana Interfaith Dialogue," https:/ems-online. org/en/projects/international-support/ghana-interfaith-dialogue/. (Accessed December 2019).

[20] K. Zurek, "Dr Chambas to Deliver Public Lecture on National Chief Imam's Centenary Celebration," 19th April 2019. Graphic Online. https:/www.graphic.com.gh/news/ general-news/dr-chambas-to-deliver-public-lecture-on-national-chief-imam-scentenary-celebration.html. (Accessed December 2019).

[21] GhanaWeb, "NationalChiefImamattends CatholicMass for 100thBirthdayThanksgiving," 21st April 2019. https://www.ghanaweb.com/GhanaHomePage/NewsArchive/NationalChief-Imam-attends-Catholic-mass-for-100th-birthday-thanksgiving-740200. (Accessed December 2019).

[22] M. Abdul-Hamid, "Christian-Muslim Relations in Ghana: A Model for World Dialogue and Peace," lorin Journal of Religious Studies Vol.1, No.1, (2011):21-32.

[23] J. Rhoda Akuaku, Christian-Muslim Relations in Ghana: The Case of Two Selected Senior High Schools Awoshie and Dansoman, A Master's Thesis Submitted to MF Norwegian School of Theology, Religion and Society, 2018.

[24] E. Obeng-Mireku, Christian-Muslim Relations in Sub-Saharan Africa: A Comparative Analysis of Ghana And Nigeria, A Master Thesis Submitted to University of Lethbridge, 2017.

[25] M. Fuseini Wandusim, "Christian-Muslim Relations in Ghana: The Role of the Youth," Journal of Advocacy, Research and Education Vol.4, No.3(2015): 223-230.

[26] C. Justice Ebo Sarbah, A Critical Study of Christian $\square$ Muslim Relations in The Central Region of Ghana With Special Reference to Traditional Akan Values, A Ph.D. Thesis Submitted to the University of Birmingham, 2010.

[27] N. Alhassan Alolo, African Traditional Religion and Concepts of Development: A Background Paper. International Development Department, University of Birmingham, 2007, pp. 14.

[28] J. Mbiti, African Religions and Philosophy. London: Heinemann,1969, pp.1.

[29] J.S. Booth, An approach to African religion. In African Religions, A Symposium (ed) J.S. Booth, New York: NOK Publishers,1977, pp.3.

[30] L. Magesa, African Religion: The Moral Traditions of Abundant Life. Maryknoll: Orbis Books, 1997.

[31] Ibid.

[32] A. Shorter, "Concepts of Social Justice in Traditional Africa," Pro Dialogo Bulletin No.12, (1977):48.

[33] E. Bolaji Idowu, African Tradition Religion: A Definition. London: SCM Press Ltd,1973.

[34] Magesa, African Religion, 18.

[35] A. Zijlma, "Travel and Culture: African Proverbs and Their Meanings," 6th March 2019. https://www.tripsavvy.com/african-proverbs-and-their-meanings-1454492. (Accessed December 2019).

[36] Prekese Ghana Media, "Ghana Nananom News Antoa: What you need to know about Antoa Nyamaa,” 3rd February 2014. https://issuu.com/prekeseghanamedia/docs/ghana nananom_news_-_antoa antoa. (Accessed December 2019). 